\title{
A economia política dos governos FHC, Lula e Dilma: dominância financeira, bloco no poder e desenvolvimento econômico*
}

\author{
Rodrigo Alves Teixeira ** \\ Eduardo Costa Pinto ${ }^{* * *}$
}

\begin{abstract}
Resumo
O presente texto analisa a relação da política macroeconômica e o desenvolvimento econômico com seus condicionantes políticos, desde 1995 até os dias atuais (governos FHC, Lula e Dilma), por meio da abordagem da economia política, aplicando os conceitos de dominância financeira, dependência e bloco no poder. Ao adotar tal método, partiu-se do pressuposto de que a adoção de determinada política econômica é decorrência: i) dos condicionantes externos, atrelados, no caso brasileiro, à sua condição periférica; ii) dos condicionantes internos associados à interação e conflitos de interesses econômicos e políticos das frações de classe no bloco no poder e em seus desenlaces no Estado. O texto conclui que as mudanças recentes no bloco no poder, entre o final do governo Lula e início do governo Dilma, conferiram maior autonomia ao Estado, especialmente diante da fração bancário-financeira, até então hegemônica, o que abre espaço para a retomada das políticas de desenvolvimento.
\end{abstract}

Palavras-chave: Dominância financeira; Dependência; Bloco no poder; Economia brasileira.

\section{Abstract \\ Economic policy during the Cardoso, Lula, and Rousseff administrations: financial dominance, power blocs and economic development}

This paper analyzes the relationship between macroeconomic policy and economic development and the political constraints of that relationship from 1995 until present day ( Cardoso, Lula and Dilma Rousseff). This analysis relies on the political economy approach, applying the concepts of financial domination, dependence and power blocs. By virute of this method, we assume that the adoption of certain economic policy is the result of: i) the external constraints (which, in Brazil, are coupled with the country's status as a peripheral and dependent economy) and ii) the constraints associated with the internal interaction and conflicts of economic and political interests of class fractions in the power bloc and its influence on the State. The paper concludes that recent changes to the power bloc between the end of the Lula administration and the beginning of the Rousseff administration gave the government greater autonomy, particularly in relation to the banking and financial sector, which was the hegemonic fraction in the power bloc. This context favors the resumption of development policies.

Keywords: Financial domination; Dependence; Power bloc; Brazilian economy.

JEL B51.

* Especial agradecimento à Leda Paulani e Reinaldo Gonçalves pelas críticas e sugestões, assumindo a versão final como de "nossa" exclusiva responsabilidade.

*** Professor do Departamento de Economia e do Centro de Estudos Pós-graduados em Economia Política da Pontifícia Universidade Católica de São Paulo (PUC-SP), São Paulo, SP, Brasil. E-mail: rateixeira@pucsp.br.

**** Professor adjunto do Instituto de Economia da Universidade Federal do Rio de Janeiro (UFRJ), Rio de Janeiro, RJ, Brasil. E-mail: eduardo.pinto@ie.ufrj.br. 


\section{Introdução}

Em uma conferência em Washington, publicada no caderno Mais! da Folha de S. Paulo em 28 de maio de 1995, o então presidente Fernando Henrique Cardoso (FHC-1995) corretamente colocou o desenvolvimento como sendo "o mais político dos temas econômicos" Não obstante, seu governo foi o que consolidou a falsa visão, difundida pela teoria econômica ortodoxa, de que a condução da política macroeconômica era uma questão técnica que deveria ser isolada dos debates políticos.

O presente texto tem como objetivo analisar a relação da política macroeconômica e o desenvolvimento econômico com seus condicionantes políticos, desde 1995 até os dias atuais (governos FHC, Lula e Dilma), por meio da abordagem da economia política. Ao adotar tal método, a análise da política econômica e a de seus resultados não ficarão restritas apenas ao campo dos debates da teoria econômica strictu sensu e suas soluções "técnicas" prescritivas que variam a depender da concepção teórica. Ao contrário, parte-se do pressuposto de que a adoção de determinada política econômica é uma decorrência: i) dos condicionantes externos, atrelados, no caso brasileiro, à sua condição periférica e dependente da economia mundial; ii) dos condicionantes internos associados à interação e conflitos de interesses econômicos e políticos das frações de classe no bloco no poder e em seus desenlaces no Estado.

À luz do objetivo proposto e do método utilizado, pretende-se responder às seguintes questões:

1) Qual foi a dinâmica das relações entre o Estado e as frações que compõem o bloco no poder do entre os governos FHC e Lula?

2) Quais as modificações do bloco no poder e nas relações entre este e o Estado no governo Dilma? Em que medida têm-se alterado as possibilidades de desenvolvimento do País como consequência de tais mudanças?

Além da introdução, o artigo divide-se em mais quatro seções. Na primeira, descrevem-se os principais pilares teóricos da economia política que servirão como fio condutor da análise: as noções de dependência, dominância financeira, bloco no poder e Estado. Tecem-se ainda, nessa seção, considerações acerca do governo FHC, caracterizando a nova forma da dependência externa que se estabelece e se consolida em seu governo e a configuração do bloco no poder que será herdada pelo governo Lula. Na seção dois, pretende-se analisar o padrão de crescimento econômico do governo Lula, destacando as relações entre as dimensões econômicas (política econômica e regime de crescimento) e políticas (relações entre classes, bloco no poder e Estado). Na seção três, enseja-se discutir a dinâmica inicial do governo Dilma, buscando identificar as possíveis mudanças que se têm processado 
no interior do bloco no poder. Por fim, procura-se alinhavar algumas ideias a título de conclusão, em particular as possibilidades que se abrem para a retomada do desenvolvimento econômico.

\section{Dependência e dominância financeira, bloco no poder e estado: caracterização teórica e histórica}

Nesta seção, apresentam-se as concepções teóricas que norteiam o trabalho, em particular, os conceitos de dependência, dominância financeira e bloco no poder. Ademais, são feitas algumas considerações acerca do governo FHC que foi decisivo para dar os contornos do bloco no poder com o qual se deparou o governo do PT em 2003. Tais considerações partem de Teixeira (2007) e de Pinto (2010), em que o leitor poderá encontrar maior detalhamento da citada caracterização.

O método utilizado, na contramão do predomínio atual das ciências econômicas que baseiam suas análises no individualismo metodológico e na separação entre economia e política, resgata aqui os conceitos de classes sociais, bloco de poder e Estado, além da noção de dependência, em uma abordagem de economia política, para a qual são inseparáveis a análise econômica e a dimensão política (relações de poder).

\subsection{Dependência, dominância financeira e governo FHC}

Não se entrará nos inúmeros debates travados entre os teóricos da dependência. Atém-se aqui a uma visão, aquela desenvolvida por Fernando Henrique Cardoso (que chega ao poder no Brasil em 1994): a versão do desenvolvimento dependente-associado. O motivo é que, como se argumentará, a concepção de Cardoso das décadas de 1960 e 1970 sobre a noção de desenvolvimento dependenteassociado permaneceu a mesma na década de $1990^{1}$ e, inclusive, orientou os aspectos fundamentais da inserção externa brasileira durante seus dois mandatos presidenciais (1995-2002).

Em seu texto clássico, Cardoso e Faletto (1975) desenvolveram o conceito de dependência a partir de uma crítica às limitações de duas grandes interpretações sobre o Brasil dos anos 1960 e 1970: i) a limitação da teoria cepalina, supondo um Estado monolítico e esclarecido para conduzir o processo de industrialização que levaria ao desenvolvimento, não tratando dos conflitos entre classes e grupos sociais no interior do Estado; ii) a limitação das teorias do imperialismo e mesmo de outros teóricos da dependência, para os quais não haveria perspectivas ao desenvolvimento pela via capitalista e dependente, em particular, porque o "imperialismo", representado pelas empresas multinacionais e Estados dos países desenvolvidos, teria interesse

(1) Isso é reforçado pelos textos em que retoma sua obra anterior, já nos anos 1990. Ver Cardoso (1994) e Cardoso (1995) 
na manutenção da condição de subdesenvolvimento e da orientação rural e agrário exportadora dos países periféricos.

Assim, enquanto as análises cepalinas e as teorias do imperialismo tratavam das relações entre nações periféricas e centrais de uma perspectiva reducionista, puramente economicista (Cepal) ou mecanicista (teorias do imperialismo), para Cardoso e Faletto, a análise do subdesenvolvimento e da dependência deveria levar em conta as relações entre sistema econômico e sistema político e social:

Há que se buscar os pontos de intersecção do sistema econômico com o sistema social, através dos quais se revelem os nexos e a dinâmica dos diferentes aspectos e níveis da realidade que afetam as possibilidades de desenvolvimento. Esquematicamente, pode-se dizer que o problema do controle social da produção e do consumo constituem o eixo de um análise sociológica do desenvolvimento orientada desta perspectiva. Com efeito, a interpretação sociológica dos processos de transformação econômica requer a análise das situações onde a tensão entre os grupos e classes sociais revele as bases de sustentação da estrutura econômica e política (Cardoso, Faleto, 1975, p. 24).

Ao caracterizar a situação de dependência, Cardoso e Faletto deixam claro que não se trata de uma relação de dominação imposta de fora para dentro. Os laços de dependência são reproduzidos pelas relações entre classes e grupos sociais domésticos e externos, de maneira que a dependência tem raízes no interior da economia dependente e o próprio subdesenvolvimento deixa de ser apenas um conceito econômico para tornar-se um conceito sociológico:

A dependência encontra assim não só “expressão" interna, mas também seu verdadeiro caráter como modo determinado de relações estruturais: um tipo específico de relação entre as classes e grupos que implica uma situação de domínio que mantém estruturalmente a vinculação econômica com o exterior. Nesta perspectiva, a análise da dependência significa que não se deve considerá-la como uma "variável externa", mas que é possível analisá-la a partir da configuração do sistema de relações entre as diferentes classes sociais no âmbito mesmo das nações dependentes. (Cardoso, Faleto, 1975, p. 31)

Para caracterizar as mudanças no tipo de dependência que vinculava a economia brasileira à mundial, os autores atentam para o aumento dos investimentos das empresas estrangeiras no país, em particular, a partir do Plano de Metas. Defendem que estaria havendo a configuração de uma nova situação de dependência, diferente da qual derivava da velha divisão internacional do trabalho em que os países periféricos inseriam-se como exportadores de bens primários, dependendo da demanda externa para seu desenvolvimento.

Naquela nova conjuntura, a burguesia industrial nacional torna-se "sóciamenor" do capital estrangeiro, limitando-se aos setores industriais tradicionais, enquanto o capital estrangeiro domina os setores mais dinâmicos. A linha política 
seguida, especialmente depois de 1964, continuou a ser, portanto, desenvolvimentista, mas neutra no que se refere ao controle nacional ou estrangeiro da economia. Destaca-se assim a novidade desta interpretação:

\begin{abstract}
A novidade da hipótese não está no reconhecimento da existência de uma dominância externa - processo óbvio - mas na caracterização da forma que ela assume e dos efeitos distintos, com referência às situações passadas, desse tipo de relação de dependência entre as classes e o Estado. Salientamos que a situação atual de desenvolvimento dependente não só supera a oposição tradicional entre os termos desenvolvimento e dependência, permitindo incrementar o desenvolvimento e manter, redefinindo-os, os laços de dependência, como se apóia [sic] politicamente em um sistema de alianças distinto daquele que no passado assegurava a hegemonia externa (Cardoso, Faleto, 1975, p. 141).
\end{abstract}

Os interesses externos estão agora ligados à produção para o mercado interno, levando a um desenvolvimento industrial da periferia que "minimiza os efeitos da exploração tipicamente colonialista e busca solidariedades não só nas classes dominantes, mas no conjunto dos grupos sociais ligados à produção capitalista moderna: assalariados, técnicos, empresários, burocratas, etc." (Cardoso, Faleto, 1975, p. 142).

Assim, para eles, o novo caráter da dependência teria eliminado a oposição entre dependência e desenvolvimento, abrindo espaço para um tipo de desenvolvimento "dependente-associado".

Em suma, os elementos centrais desta "nova dependência" são:

i) A internacionalização do mercado interno pela qual as empresas estrangeiras buscam trazer suas plantas produtivas aos países periféricos, visando ao mercado interno;

ii) A mudança no tipo de dependência que deixa de ser uma dependência do mercado externo para a dependência dos investimentos e da tecnologia estrangeiros;

iii) Rearticulam-se os laços entre elites domésticas e grupos estrangeiros, de forma que a burguesia doméstica torna-se sócia-menor dos interesses do capital estrangeiro no país. Assim, as decisões de investimento são cada vez mais transferidas ao exterior, tornando-se mais dependentes das estratégias globais;

iv) Na nova situação, apesar de se permanecer em situação de dependência, a forma dos laços de dependência altera-se, de maneira que a oposição entre dependência e desenvolvimento, presente tanto nas ideias da Cepal como nas teorias do imperialismo e outros teóricos da dependência, não era mais válida. Isso porque as empresas estrangeiras exerciam um papel cada vez mais importante na industrialização da periferia a qual era fundamental para a superação do subdesenvolvimento. 
Essa versão da teoria da dependência passa a ser voz dissonante na esquerda ${ }^{2}$, dado seu otimismo quanto às possibilidades de desenvolvimento, em contraste com as teses que não viam possibilidades de desenvolvimento pela via capitalista e sem romper os laços de dependência com os Estados imperialistas e o grande capital monopolista internacionalizado.

Segundo Cardoso (1980, p. 105), há duas formas de conceber o desenvolvimento capitalista:

- existem os que crêem que o "capitalismo dependente" baseia-se na superexploração do trabalho, é incapaz de ampliar o mercado interno, gera incessantemente desemprego e marginalidade e apresenta tendências à estagnação e a uma espécie de constante reprodução do subdesenvolvimento (como Frank, Marini e, até certo ponto, dos Santos);

- existem os que pensam que, pelo menos em alguns países da periferia, a penetração do capital industrial-financeiro acelera a produção de mais-valia relativa, intensifica as forças produtivas e, se gera desemprego nas fases de contração econômica, absorve mão-de-obra [sic] nos ciclos expansivos, produzindo, neste aspecto, um efeito similar ao do capitalismo nas economias avançadas, onde coexistem desemprego e absorção, riqueza e miséria.

Pessoalmente, acho que a segunda explicação é mais consistente, embora o tipo de "desenvolvimento dependente-associado" não seja generalizável para toda a periferia.

Uma constatação importante é que não havia, conforme exposto acima, qualquer incoerência entre FHC sociólogo e o presidente ${ }^{3}$. A noção do desenvolvimento dependente-associado mostrou-se, décadas depois, perfeitamente coerente com os ventos do neoliberalismo, o que se pode apreender do discurso proferido pelo então presidente Cardoso em Washington, quando retomou suas ideias sobre a teoria da dependência (Cardoso, 1995).

(2) Cardoso (1980) mostrava-se contrário aos demais teóricos da dependência que defendiam teses como a do "desenvolvimento do subdesenvolvimento", de André Gunder Frank e as teses do "subimperialismo" e da "superexploração", de Ruy Mauro Marini, que afirmavam, no geral, que o avanço do capitalismo na periferia traria o aumento da marginalização. No último aspecto, ele também se refere ao trabalho clássico de Francisco de Oliveira (Oliveira, 2010), "Crítica da razão dualista", na qual este autor argumenta sobre a funcionalidade das formas "arcaicas" de exploração do trabalho para a acumulação no setor moderno. Cardoso escreve que tais mecanismos de extração de mais-valia absoluta (as formas arcaicas) podem ter sido importantes no início da acumulação capitalista, mas que tenderiam a desaparecer com o desenvolvimento capitalista, pois ele está propenso a trazer o avanço tecnológico, ou seja, a busca de mais-valia relativa, que se tornaria predominante na acumulação. Cardoso critica ainda a tese de Marini de que os países periféricos estariam diante de uma encruzilhada "socialismo ou fascismo", acusando-o de catastrofista. Para ele, o progresso seria certo, desde que haja empenho em fazer avançar o capitalismo, o livre mercado, tornando o país aberto à economia mundial. O modelo anterior, centrado nos investimentos domésticos e no pacto populista, não era mais viável. Para um balanço das controvérsias entre os teóricos da dependência, ver também Santos (2000).

(3) Ao que parece, o primeiro autor a atentar para a coerência entre a teoria do desenvolvimento-associado e o projeto de FHC como presidente foi o professor José Luis Fiori, no artigo "Os moedeiros falsos", publicado no caderno Mais!, da Folha de S. Paulo, em 3 de junho de 1994. 
Para mostrar a convergência entre a versão do desenvolvimento dependenteassociado e o neoliberalismo, é preciso valer-se, aqui, do conceito de afinidades eletivas, de Max Weber, que é o mesmo método utilizado por ele em sua obra $A$ Ética Protestante e o Espírito do Capitalismo para estudar a convergência entre uma corrente religiosa (a ética protestante) e o ethos econômico (o "espírito" do capitalismo).

Michael Löwy (1989, p. 8) descreve bem o que é a noção weberiana de afinidade eletiva:

A partir de certas analogias, de certas afinidades, de certas correspondências, duas figuras culturais podem - em determinadas circunstâncias históricas entrar em uma relação de atração, de escolha, de seleção, de eleição mútua. Não se trata de um processo unilateral de influência, mas de um movimento dinâmico, ativo, de interação dialética, conduzindo, em alguns casos, à simbiose ou mesmo fusão das duas estruturas significativas.

Em termos gerais, pode-se dizer que há duas áreas de afinidade entre o neoliberalismo e a versão do desenvolvimento dependente-associado:

i) à crença no progresso trazido pelo desenvolvimento capitalista da periferia (os demais dependentistas eram céticos quanto a isso);

ii) à crença na ideia de que o desenvolvimento capitalista da periferia só será trazido por meio da abertura do mercado interno ao capital estrangeiro (os demais dependentistas, bem como o restante da esquerda, ao contrário, viam nisso o avanço do imperialismo e a condenação do país ao subdesenvolvimento e à heteronomia).

Entretanto, tal como destaca Löwy (1989), “o que transforma estas analogias puramente virtuais em relação dinâmica de afinidade eletiva é uma conjuntura histórica determinada (...)” (op. cit., p. 10). No caso da afinidade entre a tese do desenvolvimento dependente-associado e o neoliberalismo, a conjuntura histórica que a possibilitou foi, por um lado, o colapso do "socialismo real" o qual "desautorizou" as teses dependentistas vistas no socialismo como único caminho para a superação da dependência. Por outro lado, o propalado "esgotamento" do modelo de substituição de importações, enquanto um modelo que buscava a autonomia, ou seja, à consolidação de um parque industrial nacional.

O propalado esgotamento do modelo de substituição de importações foi, por sua vez, fruto também da crise fiscal do Estado desenvolvimentista, o que também abriu espaço para a convergência entre as ideias de Cardoso e o receituário neoliberal: Cardoso passou a ver no Estado uma máquina ineficiente e que estava presa aos interesses corporativos das empresas estatais e dos setores sindicalizados da burocracia, os quais seriam uma força de resistência contra a abertura da economia. O Estado ineficiente e falido em que se abrigariam forças do velho corporativismo 
deveria, em sua visão, ceder espaço à iniciativa privada e ao capital estrangeiro (Cardoso, 1994).

Como se sabe, as reformas empreendidas durante os oito anos de Fernando Henrique Cardoso (FHC) como presidente seguiam nas linhas gerais aquelas preconizadas pelo chamado Consenso de Washington, como a abertura comercial e financeira, as privatizações e as reformas pró-mercado (que eliminaram a capacidade de planejamento e intervenção do Estado na atividade econômica) e a condução ortodoxa da política econômica (juros altos e contenção de gastos correntes).

Tais reformas não proporcionaram o esperado desenvolvimento, na verdade, produziram uma situação de instabilidade macroeconômica permanente e a um padrão de crescimento stop and go, dada a elevada vulnerabilidade externa da economia no período, abalada frequentemente pelas turbulências do mercado financeiro internacional, às quais se respondia com juros elevados (para atrair o capital estrangeiro ou desestimular sua fuga) e contenção de gastos e investimentos públicos. Isso conduziu à explosão da dívida pública externa e principalmente a interna. O resultado foi a expressiva queda da formação bruta de capital da economia como porcentagem do PIB, entre 1995 e 2002, elevado desemprego e baixas taxas de crescimento, além da deterioração fiscal.

De acordo com Teixeira (2007), o fracasso do modelo implantado por FHC foi, principalmente, devido a um enorme erro de interpretação. A teoria da dependência, ao menos a versão do desenvolvimento dependente-associado, mostrou-se um arcabouço teórico com um ângulo cego, pois não foi capaz de perceber a mudança no padrão de acumulação da economia capitalista após a crise dos anos 1970 que, mais tarde seria desenvolvida por vários autores, especialmente os marxistas da vertente regulacionista e autores pós-keynesianos.

As décadas de 1980 e 1990, com a crise do desenvolvimentismo, foram de consolidação de uma inserção subordinada do Brasil no regime mundial de acumulação com dominância financeira, para usar a expressão desenvolvida por Chesnais (2005) ou a constituição de um regime de crescimento finance led, em uma perspectiva pós-keynesiana. Há vários outros trabalhos que buscam caracterizar essa inserção brasileira no regime mundial de acumulação com dominância financeira e os obstáculos trazidos para o desenvolvimento econômico. Por motivos de espaço, esse debate não será desenvolvido aqui ${ }^{4}$.

Para os propósitos desse artigo, o importante é ressaltar que a forma de inserção externa promovida pelo governo FHC, no contexto da dominância financeira da acumulação, significou a inserção subordinada do Brasil na economia mundial, criando uma nova forma das relações de dependência.

(4) Para uma discussão desse tema, ver Paulani (2006, 2008 e 2009), Paulani e Pato (2005), Teixeira (2007) e Bruno et al. (2011). 
Enquanto o otimismo de FHC eram vistos como a principal fonte de dinamismo econômico para os países periféricos, nos anos 1990, a situação econômica mundial e o papel da periferia para os fluxos internacionais de capital havia mudado de modo radical. Diante da financeirização da acumulação capitalista, conceito que passa a na interpretação dos acontecimentos da década de 1960 e 1970, quando os investimentos diretos das multinacionais têm presença cada vez mais forte nas análises econômicas marxistas e pós-keynesianas nos anos 1990 e 2000, os países periféricos não são mais vistos primordialmente como oportunidades para investimentos produtivos, mas como plataformas de valorização financeira, recebendo então a denominação de "mercados emergentes". Em tal contexto, as reformas liberalizantes de FHC, baseadas em uma transposição de sua noção de desenvolvimento dependente-associado, formulado nos anos 1960 e 1970, para os anos 1990, conduziram não a um novo ciclo de investimentos e crescimento econômico, mas sim a uma dependência financeira externa ou, em termos póskeynesianos, a uma fragilidade financeira externa e à instabilidade macroeconômica permanentes, diante de fluxos internacionais de capitais cada vez mais expressivos e voláteis.

A caracterização, no entanto, da situação de dependência, como visto, envolve, a caracterização da articulação entre o sistema econômico e o político e entre as classes e grupos sociais domésticos e externos. Nesse sentido, a fração bancário-financeira do capital (bancos, seguradoras, fundos de pensão, corretoras, agências de rating etc.) passa a deter a hegemonia no interior do bloco no poder e sua influência, a expressar-se especialmente a partir de um dos principais centros de poder no Estado: o banco central. Sua influência é exercida tanto indireta, com a propagação da ideologia da ortodoxia econômica por meio da grande imprensa e daquela especializada nos temas econômicos, como diretamente, pela troca de posições entre diretores e presidentes do Banco Central e ocupantes dos postoschave no mercado financeiro.

Destaque-se, ainda, a solidariedade ideológica e de interesses do mercado financeiro doméstico e do mercado financeiro internacional. Este último, inclusive, pelo apoio decisivo das instituições-chave do sistema financeiro internacional, o Banco Mundial e o FMI, que impunham as políticas ortodoxas ao Brasil e outras economias por meio das condicionalidades exigidas aos empréstimos e socorro às crises nos países periféricos.

De fato, no período 1994 a início dos anos 2000, o País esteve refém das constantes ameaças de fuga de capital e crises cambiais, bem como das exigências e condicionalidades dos empréstimos do FMI, o que conferiu aos grupos ligados ao mercado financeiro doméstico e internacional um poder extraordinário sobre a condução da política econômica, em detrimento de trabalhadores do setor 
privado,funcionalismo público e mesmo de outros setores das elites domésticas ligados ao setor produtivo.

Nessa configuração, na qual a fração bancário-financeira ocupa a hegemonia do bloco no poder, é que o Partido dos Trabalhadores assumirá a presidência da república em 2003.

\subsection{Hegemonia e bloco no poder: caracterização teórica}

O bloco no poder é a expressão da configuração datada das relações entre as classes dominantes em seus desenlaces no Estado capitalista. Essa especificidade histórica, segundo Poulantzas (1977, p. 224), estabelece "a relação entre, por um lado, um jogo institucional particular inscrito na estrutura do Estado capitalista, jogo que funciona no sentido de uma unidade especificamente política do poder de Estado" e, por outro lado, "uma configuração particular das relações entre classes dominantes: essas relações, na sua relação com o Estado, funcionam no seio de uma unidade política específica recoberta pelo conceito do bloco no poder".

Poulantzas (1977) assim definiu o bloco no poder: uma unidade contraditória entre distintas classes e/ou frações de classes sob a hegemonia em seu interior de uma dessas frações ou classes, em suas relações com o Estado capitalista. Nesse sentido, o conceito de bloco no poder recobre o campo das práticas políticas de classe, refletindo o conjunto das instâncias, mediações e níveis da luta de classe em uma determina conjuntura.

É preciso destacar que a hegemonia restrita de uma das frações no interior do bloco no poder é dada pela capacidade desta em liderar os interesses econômicos, políticos e ideológicos das demais frações e classes do bloco no poder. Quando a hegemonia alcança o conjunto da sociedade (dominantes e dominados), ela deixa de ser restrita e passa a ser ampla ${ }^{5}$. É preciso observar que a unificação, por meio da hegemonia (ampla ou restrita), não elimina "a luta de classe, a rivalidade dos interesses entre as frações sociais, pois encontra-se nele constantemente presente,

(5) Este termo equivale ao conceito de hegemonia utilizado por Gramsci (1978). Assim, a hegemonia ampla ocorre quando a classe dominante, ou uma de suas frações, ocupa um lugar decisivo no padrão de acumulação em determinado momento histórico e a partir de seus interesses econômicos, políticos e ideológicos consegue uma unidade orgânica ("bloco histórico") entre as demais frações das classes dominantes e dominadas. Dada a igualdade entre o conceito de hegemonia gramsciano e o de hegemonia ampla, por que então utilizar o novo termo? Isso se deve ao fato de que a hegemonia pode não ficar restrita às frações dominantes. Situação que Gramsci não contemplou, já que para ele a "sociedade política" (Estado) tinha um caráter coercitivo, cabendo tal conceito apenas à "sociedade civil" (Poulantzas, 1977). Contemporaneamente, não é factível pesar na "sociedade política" (Estado) apenas por meio da coerção, tornando necessária a utilização da hegemonia para pensar a "sociedade política" (Estado). Assim, achou-se conveniente diferenciar essas dimensões: i) hegemonia restrita (ao bloco no poder) como a situação em que a hegemonia de uma fração fica restrita ao bloco no poder dominante; ii) hegemonia ampla como o caso em que uma fração do bloco no poder consolida unidade orgânica entre dominantes e dominados . 
conservando esses interesses a sua especificidade antagônica [...]" (Poulantzas, 1977, p. 233).

O bloco no poder é formado pelas classes (e frações) que ocupam o lócus da dominação da luta política de classes, ou seja, que têm áreas de poder (centro de poder $=$ poder real) no seio do Estado. Cabe esclarecer que o bloco no poder não significa o conjunto de camadas a apoiar (classes apoios ${ }^{6}$ ) o poder de Estado, já que ele participa do espaço de dominação política. De maneira geral, a fração ou classe dominante a exercer a hegemonia restrita ao bloco no poder também é aquela que assume a hegemonia ampla. A regra geral da dupla função de hegemonia de uma determinada fração dominante depende, no entanto, da conjuntura das forças sociais. Assim, existe a "[...] possibilidade de defasagem, de dissociação e de deslocamento dessas funções de hegemonia em classes ou frações diferentes [...], que tem consequências capitais ao nível político [...]" (Poulantzas, 1977, p. 235).

Nesse sentido, o bloco no poder e sua dinâmica histórica é configurado no plano das práticas políticas de classe, diferente da cena política, já que a última circunscreve-se ao campo dos partidos políticos. A despeito de tais diferenças, os elementos citados podem interpenetrar-se, causando falsa ideia de que prática e cena são indissociáveis. Para Poulantzas (1977, p. 246), a suposta unidade entre prática e cena gerou em boa parte da ciência política contemporânea uma dupla confusão que "reduz as relações de classe às relações entre partidos, e as relações entre partidos às relações de classe". Limitou, assim, a análise das formações sociais, pois não indica os limites e as defasagens entre as práticas políticas de classe (ações do bloco no poder) e a cena política (representação dos partidos políticos para um dado regime).

Poulantzas (1977) e Marx (1986 e 2002) afirmaram que podem ocorrer, em determinada conjuntura (histórica e espacial), situações com defasagens entre o lugar de uma classe ou fração no âmbito das práticas políticas e da cena política. Uma fração pode, inclusive, deter a hegemonia restrita (ao bloco no poder) - a fração politicamente dominante -, mas não estar representada de forma orgânica por nenhum partido no sistema político que é dominado pelas frações reinantes ${ }^{7}$, muito menos constituir-se a fração detentora ${ }^{8}$ do aparelho de Estado. As três dimensões concreto-históricas podem assumir variadas combinações. Poderá também ocorrer o caso em que a fração de classe é detentora e reinante sem necessariamente fazer parte do bloco no poder.

(6) As classes apoios são as frações que, apesar de fazerem parte dos dominados, apóiam uma forma de Estado capitalista, tais como os camponeses parcelares e o lumpemproletariado proletariado no contexto bonapartista francês e a pequena burguesia no fim do primeiro período da república parlamentar francês. Os principais elementos explicativos disso são: i) as ilusões ideológicas; ii) o temor, fundado ou imaginário, do poder da classe operária.

(7) A fração reinante é a que detém partido político na cena política (Marx, 1986 e 2002; Poulantzas, 1977).

(8) A fração detentora é a que escolhe políticos, burocratas e militares das diversas frações de classe, inclusive dos segmentos dominados, para ocupar os diversos órgãos de Estado e seus núcleos de poder (Marx, 1986 e 2002; Poulantzas, 1977).a 
Assim, é preciso identificar as diferenças entre práticas e cena política, dada as três dimensões ou lugares (fração hegemônica no interior do bloco no poder; fração reinante; fração detentora) que permeiam as relações entre tais instâncias. Nesse contexto, o bloco no poder e a relação interna entre suas frações são instrumentos fundamentais para decifrarem a significação real das práticas políticas de classe, bem como (i) suas relações com os partidos que operam na cena política e (ii) suas relações com a fração política detentora do aparelho de Estado.

A partir da interconexão, o Estado deixa de ser definido por meio de ideias pré-concebidas a respeito de seu papel ativo ou passivo. $\mathrm{Na}$ verdade, a perspectiva relacional de Estado (como um campo e um processo estratégico onde se entrecruzam núcleos e redes de poder associados aos interesses de grupos e classes sociais) aqui adotada considera a combinação (em maior ou menor grau) dos dois eixos (autonomia da administração central x subordinação do Estado a determinados interesses) determinada por uma dada conjuntura espacial e temporal (Poulantzas, 1985; Oliveira, 2004).

Para Poulantzas (1985) e Codato \& Perissinotto (2001), as obras históricas de Marx sinalizam o tipo de mediação entre sociedade civil e o Estado em que o papel reprodutivo do Estado aparece tanto em um (i) nível abstrato-formal ("teoria geral do modo de produção capitalista”) quanto em um (ii) nível concreto-real. Nesse nível de abstração, a análise do papel do Estado deve levar em conta a separação entre "poder de Estado" e "poder de classe", uma vez que o Estado é o lócus em que se configuram "as lutas políticas de grupos, de facções e de frações de classe" (Codato; Perissinotto, 2001, p. 17).

O Estado assume capacidade de decisão e iniciativa relativa diante das frações do bloco no poder, inclusive sendo influenciado também, em certa mediada, por segmentos fora do bloco no poder. Isso não significa dizer que o Estado deixa de ser o espaço de dominação do bloco no poder, mas sim que, em determinadas conjunturas, é mais permeável a certas demandas dos segmentos dominados. Em tal sentido, Poulantzas (1985) afirma que o Estado pode assumir o papel de produtor, modelador ou criatura das relações objetivas em virtude de sua maior ou menor autonomia relativa (poder de Estado separado do Poder de classe).

Em linhas gerais, o Estado, na dimensão concreto-real, é o espaço de conflito das frações do bloco no poder que têm como objetivos manter ou ampliar, ao mesmo tempo, sua fatia da renda e riqueza e participação no âmbito político e ideológico (autoridade, influência e legitimidade) (Gonçalves, 2005).

Dado o leque de disputas e interesses, as políticas de Estado, no curto prazo, é o resultado das relações de forças no seio do Estado, ou seja, as políticas refletem "processos extremamente contraditórios, de medidas, de contramedidas, de blocagens, de filtragens escalonadas” (Poulantzas, 1985, p. 96). 
Caso se olhe o funcionamento do Estado, apenas nesse nível, é possível concluir que suas políticas e resultados são extremamente caóticos e contraditórios. Quando, entretanto, se observa a evolução do bloco no poder e do capital em geral, verifica-se que os resultados das políticas são a manifestações da hegemonia restrita (ou ampla) do bloco no poder que leva à ampliação da acumulação capitalista em geral e em maior grau da fração hegemônica (Poulantzas, 1985; Oliveira, 2004).

O Estado, portanto, não deve ser compreendido como uma entidade monolítica, muito menos homogênea, já que ele se constitui em um sistema institucional de aparelhos diferentes (sistema estatal) que apresenta níveis de poder diferenciados. Os aparelhos que concentram a capacidade de decidir ("poder efetivo") são os "centros de poder" do Estado. De fato, eles são os lócus institucionais em que as decisões fundamentais são efetivamente tomadas, inclusive sem nenhuma subordinação hierárquica a outras agências burocráticas. Consequentemente, estes são os locais institucionais do Estado para onde são direcionadas as principais demandas das classes ou frações de classes dominantes (Codato, 1997).

É preciso destacar que os centros de poder do sistema estatal podem modificarse ao longo do tempo, bem como podem assumir maior ou menor autonomia relativa referente a algumas frações das classes dominantes, em dada conjuntura histórica, pois seu poder não emana do fato de possuir uma força própria distinta do poder de classe (ao estilo weberiano), mas sim de sua relação no âmbito da luta de classe. Em tal contexto, o predomínio político (práticas políticas) de uma dada fração de classe é fruto "do controle ou influência que essa classe (ou seus representantes) pode exercer sobre o aparelho que concentra o poder efetivo" (Codato; Perissinoto, 2001, p. 23).

Quando o representante de uma determinada fração de classe assume os "centros de poder" do Estado, não significa dizer necessariamente que a citada fração tornou-se detentora, mas ela quase sempre é a fração hegemônica no interior do bloco no poder. A ocorrência desse fato demonstra que as frações dominantes conseguiram impor suas estratégias e objetivos mesmo sem ter de tornar-se uma classe detentora. Em outras palavras, para que uma classe ou fração consiga controlar os centros de poder do Estado, é preciso muito mais do que uma simples vitória eleitoral ${ }^{9}$.

\section{Governo Lula: política econômica, resultados macroeconômicos e dinâmica do bloco no poder}

\subsection{Regime de política macroeconômica}

As linhas mestras do regime de política macroeconômica do governo FHC (sistemas de metas de inflação, superávits primários e câmbio flutuante) foram

(9) Como será visto na próxima seção, é precisamente esse o caso do governo Lula: a vitória eleitoral do partido que representaria os interesses dos menos favorecidos não significou a ruptura com a fração bancáriofinanceira que se manteve hegemônica no interior do bloco no poder. 
mantidas pelo governo Lula. É possível, todavia, identificar em seu segundo mandato certa flexibilização na gestão da política econômica ${ }^{10}$ até então vigente.

Mesmo assim, continuou forte em vários núcleos do Estado a ideia de que as políticas econômicas só teriam efeitos sobre a estabilidade ou instabilidade de curto prazo, afetando pouco ou quase nada, o desenvolvimento econômico de longo prazo. Sob tal perspectiva, as políticas econômicas deveriam ser direcionadas à estabilidade de preços, uma vez que o crescimento seria originário do estabelecimento de normas e organizações que garantissem o direito de propriedade, à redução dos custos de transação e à melhora nas expectativas dos agentes, potencializando, então, o funcionamento completo dos mercados.

Esse tipo de regime macroeconômico, que se tornou um consenso, é sustentado no plano teórico pela new neoclassical synthesis ${ }^{11}$ por meio da articulação da adoção dos sistemas de metas de inflação, da independência do Banco Central (BC) e da política fiscal voltada estritamente à sustentabilidade da dívida pública.

No sistema de metas de inflação, qualquer atuação contracíclica do Banco Central não deveria colocar em risco a manutenção da estabilidade de preços no longo prazo, já que haveria um viés inflacionário resultante da inconsistência temporal na condução da política econômica, sem qualquer benefício em termos de produto e emprego no longo prazo (Barro; Gordon, 1983).

A questão da credibilidade da política econômica para tal teoria, ao incorporar a ideia de que agentes utilizam expectativas racionais para tomarem decisões, ganha mais destaque, criando a necessidade da consistência das políticas macroeconômicas ao longo do tempo, de tal modo que a autoridade monetária deveria comprometer-se com a estabilidade e alcance das metas. Nessa lógica, a efetivação das metas desejadas só seria possível com um Banco Central com elevado grau de independência para que suas decisões sejam tomadas sem nenhuma subordinação hierárquica a outra agência burocrática estatal. Então, supostamente eliminaria o viés inflacionário e, de forma indireta, favoreceria o desempenho econômico (Busato; Cavalcanti; Ramalhete, 2009; Serrano, 2009; Lopreato, 2006).

(10) Barbosa e Souza (2010) ressaltaram que existiu, durante o governo Lula, uma disputa de opiniões a respeito das ações da política econômica. Para eles, predominou, entre 2003 e 2005, uma visão neoliberal em que o crescimento econômico independeria das condições de curto prazo. A partir de 2006, ter-se-ia consolidado na gestão macroeconômica uma visão de que o Estado deve desempenhar um papel mais ativo no desenvolvimento econômico e social.

(11) O sistema de metas está baseado, segundo Taylor (2000), nas seguintes proposições: i) a trajetória do produto potencial independe da demanda. Apenas as condições de oferta seriam determinantes e explicadas pelo modelo de Solow; ii) existência do trade-off entre inflação e desemprego, no curto prazo, ao passo que, no longo prazo, os estímulo à demanda são neutras; iii) a rigidez temporária dos preços e salários explica a existência do trade-off entre inflação e desemprego, gerando assim, as flutuações do produto/emprego real em torno do produto potencial/natural; iv) as expectativas inflacionárias são endógenas; v) as decisões de política monetária deveriam seguir regras claras. 
Dado esse arranjo monetário, a política fiscal ocupa uma função passiva na política macroeconômica, mas central, já que a sustentabilidade da dívida pública por meio do esforço fiscal sinaliza a ausência do risco de default. Assim, a política fiscal com elevado superávit primário assume o papel de redutora do risco-país, funcionando como peça chave para conquistar a credibilidade.

No âmbito da política fiscal, o governo Lula, notadamente no $1^{\circ}$ mandato, manteve o démarche do governo anterior, qual seja: o crescimento sustentável passa pelo ajuste definitivo das contas públicas, o que significa medidas destinadas à geração de superávits primários suficientes para reduzir a relação dívida/PIB. Tal reducionismo da política fiscal - que implicitamente significa preservação da riqueza financeira - limitou a capacidade do Estado em ampliar os investimentos públicos.

No $2^{\circ}$ governo Lula, verificou-se certa flexibilização da política econômica por meio (i) da adoção de medidas voltadas à ampliação do crédito ao consumidor e ao mutuário, (ii) do aumento real no salário mínimo, (iii) da adoção de programas de transferência de renda direta, (iv) da criação do Programa de Aceleração do Crescimento (PAC) e da ampliação da atuação do BNDES para estimular o investimento público e privado e (v) das medidas anticíclicas de combate à crise internacional a partir de 2009.

De maneira geral, a condução da política econômica do governo Lula foi fortemente influenciada pela ortodoxia econômica, especialmente no primeiro mandato. Essa situação foi caracterizada por Paulani (2008) como um constante "estado de emergência econômico", em que as políticas ortodoxas, contrárias aos interesses dos grupos sociais tradicionalmente representados pelo Partido dos Trabalhadores, eram sempre justificadas pelas ameaças das fugas de capital, das crises cambiais e da volta da inflação, que estariam sempre rondando a economia.

\subsection{Desempenho e dinâmica macroeconômica}

Os resultados macroeconômicos (setor externo, nível de atividade, inflação, emprego e renda e finanças públicas) dos dois governos Lula foram melhores do que os de seu antecessor. Entre 2003 e 2010, o Brasil atravessou o maior ciclo de crescimento das últimas três décadas. O PIB cresceu $4,1 \%$ ao ano, quase o dobro do observado entre 1980 e 2002 (2,4\% ao ano).

As contas externas da economia brasileira no governo Lula apresentaram resultados muito positivos expressos nos superávits do balanço de pagamentos entre 2003 e 2010 (US\$231,8 bilhões no acumulado). Isso permitiu ao governo saldar os empréstimos com o FMI, diminuir o endividamento público externo e acumular reservas (Cintra; Acioly, 2012). 
Esse resultado favorável foi impulsionado pelo contexto internacional (i) de crescimento mundial até a crise de 2008, (ii) de ampla liquidez dos mercados financeiros e (iii) de elevação dos preços internacionais das commodities e de queda dos preços das manufaturas decorrentes do efeito direto e indireto da China. As modificações nos preços geraram, entre janeiro de 2003 e dezembro de 2010, uma elevação de 39,9\% nos termos de troca do Brasil. Para Barbosa (2011), significou um bônus macroeconômico para país, permitindo um crescimento sem gerar graves desequilíbrios externos e internos.

Durante o governo Lula, é possível identificar dois momentos positivos e distintos do setor externo. Entre 2003 e 2006, os elevados superávits comerciais, superiores aos déficits estruturais da conta de serviços e renda, foram os principais responsáveis pela melhora das contas ${ }^{12}$. Entre 2007 e 2010, os superávits na conta capital e financeira foram os maiores impulsionadores positivos ${ }^{13}$

Arápida recuperação das contas externas brasileira no pós-crise internacional, puxado pelos fluxos líquidos de capitais, deu-se pelo "excesso de liquidez" da economia mundial. Parte dessa massa de capital-dinheiro deslocou-se para o Brasil em virtude da alta rentabilidade das aplicações em carteira (diferencial entre a taxa Selic e a internacional) e da recuperação rápida da atividade econômica com expansão do mercado interno, abrindo novos mercados rentáveis para investidores estrangeiros em um contexto internacional de estagnação econômica na Europa e nos Estados Unidos.

As taxas médias de crescimento do PIB nos dois governos Lula (3,5\% entre 2003 e 2006; 4,6\% entre 2007 e 2010) foram maiores do que as dos dois governos FHC (2,4\% entre 1995 e 1998; 2,1\% entre 1999 e 2002). Entre 2003 e 2010, o consumo das famílias e os investimentos públicos e privados, -Formação Bruta de Capital Fixo (FBKF) - elevaram-se em 4,5\% e 7,5\% ao ano em média, respectivamente. A expansão do investimento acima do PIB implicou na elevação da FBKF de 15,3\% PIB em 2003 para 19,5\% em 2010.

Mesmo com tamanha expansão, a inflação Índice Nacional de Preços ao Consumidor Amplo (IPCA) durante o governo Lula ficou quase sempre próxima ao centro da meta. Em 2006, 2007 e 2009, por exemplo, a inflação foi menor do que

(12) Entre 1999-2002 e 2003-06, o saldo acumulado da balança comercial aumentou 976\% (de US\$13,9 bilhões para US\$ 149,6 bilhões). Esse nível de superávit comercial (fruto da expansão de $23 \%$ a.a. em média das exportações acima dos $18,4 \%$ das importações a.a. em média entre 2003 e 2006) provocou a reversão do sinal da conta-corrente (deficitária todos os anos entre 1995 e 2002) que passou a ser superavitária entre 2003 e 2007, pois o déficit acumulado da conta de serviços e renda, entre 1999-02 e 2003-2006, cresceu 18,3\% (de R\$101,5 bilhões para R\$120,1 bilhões).

(13) A conta capital e financeira, entre 2007 e 2010 passou a apresentar superávits recordes (US\$ 88,3 bilhões em 2007, US\$ 70,2 bilhões em 2009 e US\$ 99 bilhões em 2010) e muito superiores aos montantes necessários para financiar a conta de transações correntes. Com isso, o balanço de pagamentos registrou superávits expressivos no $2^{\circ}$ governo Lula (Cintra; Acioly, 2012). 
a meta. O controle da inflação esteve atrelado ao processo de apreciação do real (42,8\% entre 2003 e 2010).

No que tange ao mercado de trabalho, verificaram-se dois padrões diferenciados durante o governo Lula, a saber: i) entre 2003 e 2006, quando ocorreu uma pequena redução na taxa de desemprego das Regiões Metropolitanas (RM's) (de 12,3\% em 2003 para 10\% em 2006) e uma queda real de 5,0\% na massa de rendimentos médios dos ocupados nas RM's; ii) entre 2007 e 2010, quando se verificou uma redução expressiva das taxas médias de desemprego na RM's (de 9,3\% em 2007 para 6,7\% em 2010) e uma melhora significativa da massa real de rendimentos dos ocupados (crescimento de cerca de 20\%). Cabe destacar ainda o crescimento real do salário mínimo ao longo do governo Lula (expansão média de $5,9 \%$ a.a.) que teve efeitos positivos para demanda agregada e para a distribuição de renda.

As finanças públicas também melhoraram no governo Lula, notadamente no $2^{\circ}$ mandato, pois a dívida líquida total do setor público veio caindo desde 2003 (54,9\% PIB em dez/2003) até 2010 (39,2\% PIB em dez/2010). O principal fator dessa queda foi a redução sistemática da dívida externa desde o início do governo. Em dezembro de 2006, o setor público passou a condição de credor externo (R\$ 27,8 bilhões) que foi ampliado a cada ano até atingir o valor de R $\$ 359,7$ bilhões de créditos externos em dezembro de 2010.

Essa trajetória positiva da dívida líquida externa deveu-se diretamente aos elevados saldos da balança comercial, entre 2003 e 2006, e da conta financeira, entre 2007 e 2010 . Isso possibilitou ao governo elevar suas reservas em dólar (de US\$ 49,3 bilhões em 2003 para US\$ 85,8 bilhões em 2006 para US\$ 180,3 bilhões em 2007 até os US\$ 352,0 bilhões em 2010), reduzindo assim a dívida líquida externa a ponto de tornar-se credor líquido.

O lado negativo da evolução das finanças públicas, dada a manutenção do elevado nível da taxa de juros, foi a elevação de forma sistemática da dívida líquida interna do setor público que passou de 43,5\% do PIB em dezembro de 2003 para $48,7 \%$ do PIB em dezembro de 2010. Evolução esta que, segundo Marques-Pereira \& Bruno (2010), é explicada pela trajetória real de juros da SELIC, expressa pelo fator de capitalização composta de juros reais sobre o estoque da dívida líquida interna do setor público consolidado.

Os elevados superávits primários durante o governo Lula ( $\mathrm{R} \$ 758,8$ bilhões no acumulado entre 2003 e 2010) foram menores do que os montantes pagos de juros no mesmo período ( $\mathrm{R} \$ 1.491,4$ bilhões). Os superávits não foram pequenos, o que o correu foi que a manutenção de taxa de juros elevada gerou grandes custos ficais e o contínuo aumento da dívida interna em termos absolutos. Os juros - que caíram 
em \% PIB, mas se elevaram em termos absolutos - alimentaram os segmentos financeirizados, em especial a fração hegemônica do bloco no poder, a bancáriofinanceira.

Esses resultados macroeconômicos evidenciaram dinâmicas diferentes entre o $1^{\mathrm{o}}$ e o $2^{\mathrm{o}}$ governos Lula. No primeiro, o crescimento brasileiro foi fortemente impulsionado pela dinâmica externa de forma direta (aumento das exportações) e indireta (elevação dos investimentos dos setores exportadores). No segundo, irão somar-se a dinâmica externa favorável, a expansão do mercado interno que foi fruto da flexibilização da orientação contracionista da política econômica.

De fato, os dados do setor externo brasileiro e seus efeitos sobre a economia brasileira explicam a evolução positiva entre 2003 e 2006. A redução da restrição externa e a expansão do PIB no período estiveram associadas às mudanças internacionais favoráveis que geraram um extraordinário boom nos preços das commodities que o Brasil exporta e à redução dos preços das manufaturas e dos bens de capital importadas pelo país. O setor externo assumiu papel relevante para o nível de atividade no primeiro governo Lula tanto no que diz respeito (i) aos "efeitos primários" do aumento das exportações, que são, por um lado, importantes componentes dos gastos autônomos (da demanda agregada) ${ }^{14}$ e, por outro lado, contribuem para remover a restrição externa a que estão sujeitas economias subdesenvolvidas; (ii) ao "efeitos secundários" do aumento das exportações que resultam em maior renda agregada interna, induzindo o investimento por meio do efeito acelerador, particularmente daquelas empresas/grupos econômicos que destinam sua produção para exportação ${ }^{15}$ (Pinto, 2010).

A partir de 2006 (último ano do $1^{\circ}$ governo Lula) e ao longo do $2^{\circ}$ mandato de Lula, irá somar-se aos fatores externos a importante expansão do mercado interno, decorrente de certa flexibilização da orientação constracionista da política econômica. Essa flexibilização, associada às benesses externas, criou uma expansão econômica sustentada pelos investimentos e consumo das famílias (crescimento médio entre 2007 e 2010 de $10,5 \%$ e de $5,8 \%$, respectivamente) que parece ter criado a partir de 2006 um consumo de massas o qual articula crescimento e distribuição de renda.

Além das políticas de renda e distributivas, a expansão do mercado interno foi estimulado por meio de políticas creditícias expansionistas e das medidas de combate à crise internacional. Entre dezembro de 2003 e dezembro de 2010, o

(14) As exportações a partir de 2003 passaram a contribuir de forma crescente para o resultado do PIB. A taxa média de contribuição das exportações para o crescimento do PIB, entre 2003 e 2006, foi de 1,5\%, o equivalente a, aproximadamente, $42,8 \%$ do crescimento do PIB médio no mesmo período $(3,5 \%)$.

(15) $\mathrm{O}$ aumento das exportações induziu o aumento dos investimentos, em termos absolutos e relativos, dos grupos econômicos da indústria de commodities intensiva em capital, puxando a expansão dos investimentos entre 2003 e 2006. Para uma análise detalhada a partir dos dados desagregados da PIA (Pesquisa Industrial Anual-IBGE) e dados dos lucros líquidos e das taxas de lucros dos grupos econômicos, ver Pinto (2010) 
crédito expandiu-se de $26,1 \%$ do PIB para 45,2\% do PIB. Além da expansão do crédito pelos bancos públicos durante a crise de setembro de 2008, outras medidas foram adotadas pelo governo, tais como reduções das alíquotas do IR e do IPI sobre carros novos, material de construção e eletrodomésticos, do IOF nas operações de crédito das pessoas físicas e da COFINS sobre motos.

Apesar da direção correta da política fiscal, observou-se que ela foi de baixa intensidade se comparada com intervenções de outros países, já que não se abriu mão da geração de superávit primário. Juntamente a tais medidas fiscais, ocorreu a redução da taxa de juros Selic a partir de janeiro de 2009 que passou de 13,75\% a.a. para $8,75 \%$ a.a. em junho de 2009. O corte, no entanto, dos juros feitos pelo Banco Central teve um caráter retardatário, segundo Barbosa e Souza (2010), em virtude da preocupação excessiva do $\mathrm{BC}$ sobre os impactos inflacionários da depreciação do real no auge da crise. A economia brasileira recuperou-se rapidamente da crise devido à recuperação do setor externo e ao crescimento do consumo das famílias de 4,4\% em 2009, auge da crise no Brasil.

\subsection{Bloco no poder e hegemonia no governo Lula}

Durante o governo Lula, verificaram-se mudanças nos fluxos e estoques de riqueza das frações que compõem o bloco no poder, fruto da política macroeconômica e da própria dinâmica econômica. "A acumulação de ativos ou passivos promove igualmente a criação e distribuição de outra substância, mais dificilmente mensurável (e cujo nome é quase um tabu entre economistas), e que vem a ser o poder político". Com isso, "o acompanhamento da dinâmica de fluxos e estoques [da riqueza] fornece pistas importantes" para "a economia política desses processos" (Macedo; Santos, 2008, p. 16).

Nesse sentido, o regime de política macroeconômica durante o governo Lula foi a expressão dos movimentos contraditórios desenvolvidos no aparelho de estado que, mesmo parecendo caóticos e contraditórios no curto prazo, são a evidência dos interesses hegemônicos da fração bancário-financeira nacional e internacional no bloco no poder. A variável-síntese do processo foi a taxa de juros.

A partir de tal perspectiva, o debate a respeito do nível da taxa de juros não pode ser resumido apenas ao campo do pensamento econômico e de suas soluções técnicas, já que a específica variável é o elemento central para expressar os conflitos das frações do bloco no poder. Em outras palavras, o manejo do regime de política macroeconômica condensa ao mesmo tempo: i) a dimensão das soluções técnicas prescritivas de doutrinas do pensamento econômico; ii) o poder político da fração bancário-financeira que se materializa por sua representação no "centro de poder" do sistema estatal brasileiro: o Banco Central; iii) o poder econômicos dessa fração bancário-financeira que pode ser observado pelas elevadas taxas de lucros dos grupos econômicos dos segmentos bancário-financeiro; iv) o poder ideológico da citada 
fração que conseguiu incorporar de forma incontestável ao conjunto da sociedade a ideia de que o combate à inflação deve ser realizada a qualquer custo e, mais importante, com um único instrumento: a taxa de juros elevada.

Dentre os efeitos dessa dinâmica dos fluxos e estoques de riqueza, Pinto (2010) destaca o aumento relativo do poder da grande burguesia produtora e exportadora de commodities. Entre 1995 e 2007, os lucros líquidos reais dos grupos econômicos de tal segmento cresceram 1.705,9\% (de R \$ 2,0 bilhões para R \$ 36,1 bilhões), provocando aumento em sua participação em relação aos lucros totais (de 30,7\% em 1995 para 44,0\% em 2007) para uma amostra com os 300 maiores grupos econômicos do país (responsáveis por cerca de $40 \%$ da riqueza anual em média gerada no Brasil). Em 2007, esse setor passou a ter a maior participação, ultrapassando o segmento bancário-financeiro (33,5\%) (Gráfico 1 e 2).

Gráfico 1

Evolução real dos lucros líquidos do IC e SF (1995 = base deflacionados pelo IPCA)

(R\$ bil)

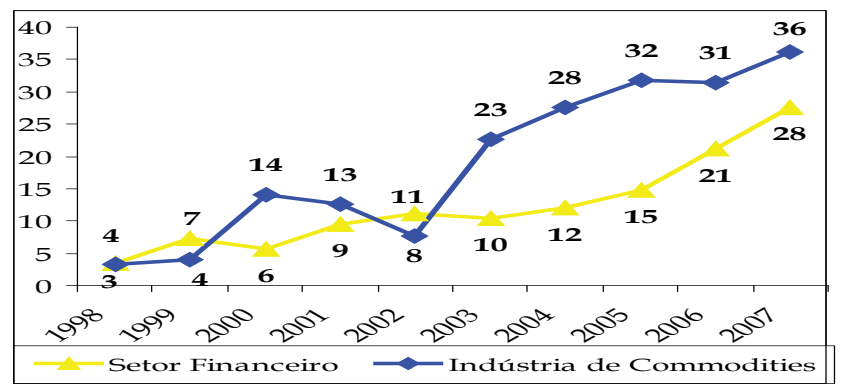

Nota: Setores: IC - Indústria de Commodities; SF - Setor financeiro.

Fonte: Balanço Anual da Gazeta Mercantil.

Gráfico 2

Evolução da participação (\%) dos lucros líquidos por setores de atividade

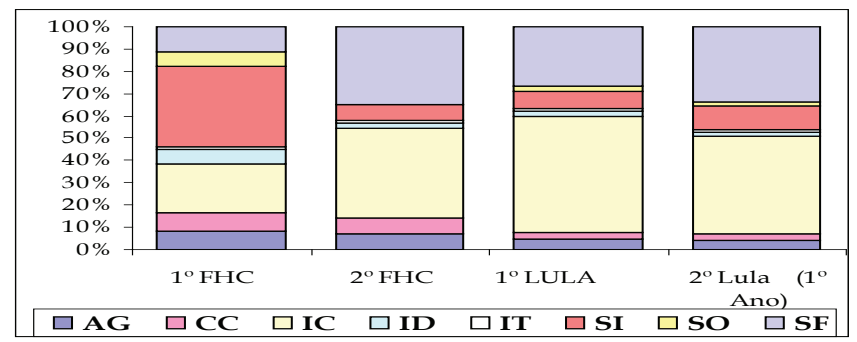

Nota: AG-Agronegócio; CC-Construção Civil; IC-Indústria de Commodities; ID-Indústria Difusora; IT- Indústria Tradicional; SIServiços de Infraestrutura; SO- Outros Serviços. Fonte: Balanço Anual da Gazeta Mercantil 
Cabe observar que esse forte aumento da participação do lucro líquido da indústria de commodities intensivos em capital (IC) foi fortemente influenciado pelos desempenhos (elevados lucros) da Vale e Petrobrás, já que os dois grupos foram responsáveis por mais de $50 \%$ dos lucros líquido da IC $\left(61,8 \%\right.$ no $1^{\circ}$ governo Lula e $63,3 \%$ no primeiro ano, $2^{\circ}$ governo Lula).

$\mathrm{O}$ avanço dos segmentos industriais produtores de commodities e do agronegócio, durante o governo Lula, teve muito mais a ver com a dinâmica internacional do que com políticas estatais. Isso ficou evidente com a manutenção do regime de política macroeconômica, com juros elevados, que gerou valorização cambial, impactando negativamente nos ganhos dos setores mais do que compensados pelo aumento dos preços internacionais das commodities.

A explicação para o fato é dada pela extraordinária dinâmica mundial conduzida pelo eixo sino-americano, já que os efeitos positivos dos preços e do quantum das exportações brasileiras foram bem superiores aos efeitos negativos da valorização cambial. Sem dúvida, existe um conflito latente entre as frações da grande burguesia exportadora e a grande burguesia bancário-financeira no manejo da taxa de juros e do câmbio. Os efeitos, contudo, da expansão do eixo sino-americano sobre as exportações brasileiras reduziram fortemente esse conflito. Como os sinais atuais indicam ter a China, após a crise, acelerado seu processo de catch-up, é possível que os rebatimentos desse processo sobre as exportações brasileiras garantam, por um bom período, a soldagem dos interesses entres as duas frações, a não ser que haja uma desaceleração mais forte naquele país.

A taxa de juros em níveis elevados, em um contexto de câmbio flexível, provocou a valorização do real que implicou no barateamento dos produtos importados e a redução dos ganhos dos exportadores. Tal processo provocou a redução do poder econômico e político das frações da grande burguesia industrial, sobretudo no primeiro governo lula, que destina sua produção ao mercado interno.

A partir de 2006, com o crescimento da economia puxado também pela dinâmica interna, verificou-se certo fortalecimento dos segmentos nacionais da indústria e do comércio que passaram a exercer maior influência sobre os núcleos de poder do Estado brasileiro.

As mudanças na posição relativa do bloco no poder não significaram, até a crise internacional, um deslocamento na hegemonia da fração da grande burguesia bancário-financeira, mas sim uma redução do seu poder relativo.

A manutenção da hegemonia desse segmento durante o governo Lula pode ser evidenciada, no plano econômico, pelo aumento de seu estoque de riqueza e pela elevação dos lucros líquidos (Gráfico 1) e das taxas de lucros que saltaram de 15,5\% 
em 2003 para 25,1\% em 2007 (Gráfico 3). O aumento foi fruto tanto das elevadas taxas de juros básicas como dos altos spreads bancários (Pinto, 2010).

Gráfico 3

Evolução da taxa de lucro do IC e SF - 1995-2007 (\%)

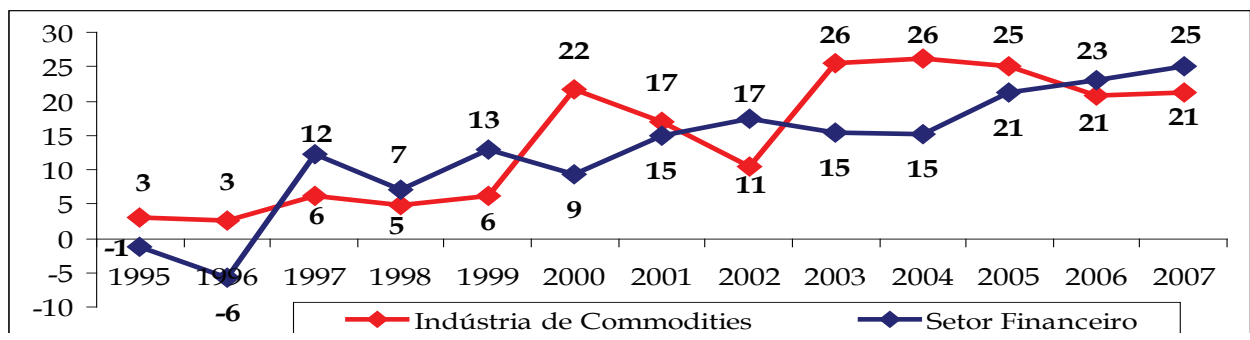

Nota: Setores: IC - Indústria de Commodities; SF - Setor financeiro

Fonte: Elaboração própria a partir do Balanço Anual da Gazeta Mercantil

Os dados apresentados por Marques e Bruno (2010) a respeito das origens das receitas do sistema bancário-financeiro no Brasil evidencia que, a partir de 2001 até 2007, o maior componente das receitas do sistema bancário-financeiro foi a renda de títulos e valores mobiliários que é constituída, basicamente, por títulos da dívida pública interna. Dado que a taxa real de juros da Selic, por seu fator capitalizado, é positivamente correlacionada com os títulos da dívida pública interna, pode-se inferir que a manutenção de elevadas taxas de juros permite a manutenção do poder econômico e político da fração bancário-financeira.

O poder econômico do segmento bancário-financeira, viabilizado pelo regime de política macroeconômica, foi a expressão de seu poder político no aparelho de Estado, materializado pela independência operacional do Banco Central - principal "centro de poder" do sistema estatal brasileiro - comandado por representantes dos interesses diretos e indiretos dessa fração.

A independência operacional do BC foi a maior expressão do poder político do repectivo segmento, a despeito dos argumentos em defesa de tal medida, que advogam que isso garantiria a despolitização do debate, ou seja, as medidas tomadas seriam soluções técnicas prescritivas construídas de forma neutra. É evidente que esse argumento é uma falácia, pois os resultados das medidas adotadas pelo BC geram ganhadores e perdedores. Foi a fração bancário-financeira que mais ganhou.

No plano ideológico, a fração bancário-financeira conseguiu legitimar de forma incontestável, ao menos até a crise internacional de 2008, ao conjunto da sociedade a ideia de que o combate à inflação deve ser realizado independentemente de seus custos. 
Os condicionantes internos (políticas econômicas) e externos (efeito do eixo sino-americano), no âmbito da luta economia e política de classes, foram a causa e o efeito da dinâmica cooperativa e conflituosa das frações de classe do bloco no poder.

As mediações e os impactos dos dois condicionantes sobre o bloco no poder ficaram relativamente claros. Em contrapartida, ainda não são tão evidentes os impactos de tais elementos, durante o governo Lula, para os segmentos fora do bloco no poder (dominados). Existe atualmente um interessante debate sobre esse tema. Destaca-se aqui a interpretação de André Singer sobre o chamado "lulismo".

Para Singer (2009), o tripé formado pela Bolsa Família, aumento do salário mínimo e expansão do crédito, que gerou redução da miséria, vai muito além da simples ajuda aos pobres, pois para ele esse tripé e o regime de política macroeconômica constituem nova plataforma - articulando valores de direita (manutenção da ordem - combate à inflação) e de esquerda (políticas de distribuição de renda), no sentido de delinear uma trajetória política de certa fração de classe, a saber: o subproletário . Assim, Lula, ao fazer isso, estaria criando uma ligação ideológica com os mais pobres, tornando-se o representante das frações, materializada pelos votos, sobretudo a partir da eleição de 2006. "À medida que passou a ser sustentado pela base subproletária, Lula obteve uma autonomia bonapartista [...]. Com ela, criou um ponto de fuga para as luta de classes, que começou a ser arbitrada ao sabor da correlação de forças". Tornou-se, inclusive, um “árbitro acima das classes” (Singer, 2009, p. 102).

A análise de Singer (2009) é muito interessante para tratar da mudança nas bases eleitorais do partido dos trabalhadores e, em especial, do presidente Lula. Ao argumentar, no entanto, que houve ligação direta entre frações de classes e partidos políticos (cena política), Singer parece desconsiderar que, em determinadas conjunturas históricas, podem existir defasagens entre o lugar de uma classe ou fração no âmbito das práticas políticas (bloco no poder) e da cena política (sistema partidário). Isso o leva a afirmar que o Brasil eleitoral, em 2006, dividiu-se entre ricos e pobres. Considera-se que essa análise simplifica muito a questão.

Ainda que seja incontestável o realinhamento eleitoral, uma vez que nas eleições de 2006, pela primeira vez o partido dos trabalhadores - cujos votos tradicionalmente concentravam-se nos extratos médios e de maior escolaridade teve o voto do "andar de baixo" (o subproletariado), a análise de Singer deixa de lado outro realinhamento, fundamental para compreender a dinâmica do "andar de cima". Analisando-se os valores doados, entre as eleições de 2002 e de 2006, para a campanha eleitoral de Lula, de acordo com dados de Filgueiras e Gonçalves (2007), vê-se um expressivo aumento dos recursos doados pelo setor financeiro (que passam de R \$ 6.080 milhões para de R 12.705 milhões), pelo setor de construção civil (de $\mathrm{R}$ \$ 2.490 milhões para de R\$ 18.028 milhões) e pelo setor primário-exportador e 
indústria de commodities (de R $\$ 1.610$ milhões para de $\mathrm{R}$ \$ 12.511 milhões). Assim, percebe-se em 2006 outro realinhamento eleitoral, não tão expressivo em número de votos quanto o realinhamento apontado por Singer, mas muito expressivo em cifras.

Deixar de lado a análise dos efeitos das políticas do governo Lula sobre os setores dominantes significa construir uma visão parcial do período. Embora tenha havido uma ligação direta entre Lula e o subproletariado (lulismo), promovida pelos programas de transferência direta de renda, pelo aumento do salário mínimo, pelo crescimento da massa salarial e do emprego, tal ligação não significa uma plataforma política para a fração dominada, mas sim uma política que possibilita a legitimação da dominação das frações do bloco no poder, com a incorporação de parte dos mais pobres ao consumo capitalista, com forte crescimento da chamada classe $\mathrm{C}$, paralelamente à redução das classes E e $\mathrm{D}$ e da pobreza extrema.

Assim como os camponeses parcelares serviram de classe apoio para a dominação de classe no bonapartismo francês, o subproletariado brasileiro tem funcionado como uma "classe apoio", no plano político, do governo Lula, que manteve a dominação de classe do bloco no poder. A diferença do subproletariado brasileiro atual em relação aos camponeses parcelares franceses no período bonapartista é que o primeiro também obteve benefícios econômicos, além do convencimento ideológico que foi a marca da relação entre os camponeses parcelares e o governo.

Assim, a hipótese defendida por Singer de que o apoio do subproletariado teria vindo por um lado das políticas de redistribuição de renda e por outro lado da manutenção da política econômica (sem rupturas), atribuindo a esse subproletariado um caráter conservador, merece ressalvas. Acredita-se ser questionável afirmar o caráter conservador do subproletariado com respeito à política macroeconômica, em particular por ele constituir-se de uma parcela da população em grande parte imune à propagação da ideologia das doutrinas econômicas ortodoxas pelo bombardeio diário da grande imprensa, seja por não ser leitora assídua de jornais e revistas conservadoras de grande circulação, seja pelos debates macroeconômicos não serem de fácil compreensão para a ampla maioria da população.

Em particular, a atribuição do conservadorismo ao subproletariado já supõe um desconhecimento, por parte deste, dos temas macroeconômicos, pois a continuidade e avanço das políticas sociais que beneficiam esses segmentos são limitados pela política macroeconômica ortodoxa, caracterizada pela redução de gastos correntes e juros elevados. Tais juros, por sua vez, trazem aumento do desemprego e maior parcela de gastos com juros da dívida pública e, consequentemente, redução dos recursos disponíveis para as políticas sociais. Pelo exposto, não parece plausível a hipótese do conservadorismo em matéria de política macroeconômica que Singer atribui ao subproletariado. 
O mais plausível é dizer que a manutenção da política macroeconômica de FHC não foi um fator que contribuiu para o realinhamento eleitoral deste grupo, mas sim para o realinhamento das elites hegemônicas do bloco no poder. $\mathrm{O}$ apoio do subproletariado ao governo Lula, conseguido com os programas de transferência de renda e o aumento do salário mínimo, ao lado da manutenção da política econômica, possibilitou a manutenção da dominação da fração bancário-financeira no bloco no poder. Mais que isso, completou-se o processo de legitimação uma vez que a hegemonia restrita da fração bancário-finaceira, durante o governo FHC, torna-se uma hegemonia ampla, incorporando os segmentos fora do poder.

Apesar da manutenção e da legitimidade do bloco no poder durante o governo Lula, os dois últimos anos de seu mandato, notadamente após a profunda crise internacional de 2008, começaram a aparecer mudanças mais estruturais no bloco no poder brasileiro, potencializando fissuras na hegemonia da fração bancáriofinanceira, em virtude do fortalecimento de outras frações (segmentos exportadores de commodities e de parte da indústria nacional que passou a recuperar-se em termos absolutos) e dos efeitos econômicos e ideológicos da crise financeira internacional.

\section{Governo Dilma: crise internacional, fissuras no bloco no poder e oportunidades para a retomada do desenvolvimento}

A redução dos juros adotada pelo Banco do Brasil e Caixa Econômica e o discurso contundente da presidenta Dilma Rousseff no dia $1^{\circ}$ de maio de 2012, cobrando mudanças dos bancos privados em relação aos elevados juros e spreads , sinalizaram mudanças nas relações entre o sistema financeiro e o Estado brasileiro.

Seria tal mudança, decorrência do estilo mais contundente da presidenta Dilma em comparação com o mais conciliador do ex-presidente Lula? Os que acreditam nisso entendem que o poder estatal decorreria do fato de ele possuir uma força própria distinta do poder de classe.

Nessa visão simplista, a política econômica seria configurada por meio de um desenho de especialistas destituídos de interesses de classe, bastando apenas ao governante ter vontade política para realizar mudanças. Os economistas que adotam essa linha esvaziam a política, pois deixam de lado os condicionantes internos ao Estado (sua ossatura e disputas - lócus político em que se travam os embates entre os segmentos dominantes do bloco no poder e os populares), fundamentais para compreender a construção e a adoção das medidas estatais.

Argumenta-se aqui que as recentes mudanças nas relações entre a fração bancário-financeira e o Estado brasileiro não podem ser apreendidas apenas pelo estilo de governar da presidenta Dilma, mas são fruto das mudanças em curso no Brasil e no mundo que tem propiciado ao Estado maior autonomia relativa diante 
O mais plausível é dizer que a manutenção da política macroeconômica de FHC não foi um fator que contribuiu para o realinhamento eleitoral deste grupo, mas sim para o realinhamento das elites hegemônicas do bloco no poder. O apoio do subproletariado ao governo Lula, conseguido com os programas de transferência de renda e o aumento do salário mínimo, ao lado da manutenção da política econômica, possibilitou a manutenção da dominação da fração bancário-financeira no bloco no poder. Mais que isso, completou-se o processo de legitimação uma vez que a hegemonia restrita da fração bancário-finaceira, durante o governo FHC, torna-se uma hegemonia ampla, incorporando os segmentos fora do poder.

Apesar da manutenção e da legitimidade do bloco no poder durante o governo Lula, os dois últimos anos de seu mandato, notadamente após a profunda crise internacional de 2008, começaram a aparecer mudanças mais estruturais no bloco no poder brasileiro, potencializando fissuras na hegemonia da fração bancáriofinanceira, em virtude do fortalecimento de outras frações (segmentos exportadores de commodities e de parte da indústria nacional que passou a recuperar-se em termos absolutos) e dos efeitos econômicos e ideológicos da crise financeira internacional.

\section{Governo Dilma: crise internacional, fissuras no bloco no poder e oportunidades para a retomada do desenvolvimento}

A redução dos juros adotada pelo Banco do Brasil e Caixa Econômica e o discurso contundente da presidenta Dilma Rousseff no dia $1^{\circ}$ de maio de 2012, cobrando mudanças dos bancos privados em relação aos elevados juros e spreads , sinalizaram mudanças nas relações entre o sistema financeiro e o Estado brasileiro.

Seria tal mudança, decorrência do estilo mais contundente da presidenta Dilma em comparação com o mais conciliador do ex-presidente Lula? Os que acreditam nisso entendem que o poder estatal decorreria do fato de ele possuir uma força própria distinta do poder de classe.

Nessa visão simplista, a política econômica seria configurada por meio de um desenho de especialistas destituídos de interesses de classe, bastando apenas ao governante ter vontade política para realizar mudanças. Os economistas que adotam essa linha esvaziam a política, pois deixam de lado os condicionantes internos ao Estado (sua ossatura e disputas - lócus político em que se travam os embates entre os segmentos dominantes do bloco no poder e os populares), fundamentais para compreender a construção e a adoção das medidas estatais.

Argumenta-se aqui que as recentes mudanças nas relações entre a fração bancário-financeira e o Estado brasileiro não podem ser apreendidas apenas pelo estilo de governar da presidenta Dilma, mas são fruto das mudanças em curso no Brasil e no mundo que tem propiciado ao Estado maior autonomia relativa diante das frações de classes. 
Nos dois últimos anos do governo Lula, começaram a aparecer fissuras na hegemonia da fração bancário-financeira em decorrência tanto do fortalecimento de outras frações (segmentos exportadores e de parte da indústria nacional) como dos efeitos econômicos e ideológicos da crise financeira internacional.

A política deliberada de acúmulo de divisas, que possibilitou as medidas anticíclicas de combate à crise internacional, evidenciou a redução das restrições externas do país. Então, reduziu-se o poder dos mercados financeiros doméstico e internacional em questionar a orientação da política econômica nacional por meio de saídas abruptas de capital. Ademais, no plano político/ideológico, a crise internacional desgastou a teoria econômica ortodoxa cuja ideia de que mercados financeiros livres, associados a Bancos Centrais independentes, seriam os mecanismos mais eficientes em promover o bem-estar da população.

As mudanças nas relações entre o sistema financeiro e o Estado brasileiro (política monetária menos ortodoxa com redução mais rápida da Selic, redução dos juros dos bancos públicos etc.) ficaram mais claras no governo Dilma e expressam a ruptura da hegemonia do segmento bancário-financeiro no bloco no poder. Isso não significa dizer que o segmento irá deixar de obter elevadas taxas de lucro, mas que (i) ele já não tem a capacidade alcançar seus objetivos por cima dos outros interesses dos demais segmentos do bloco no poder e fora dele e que (ii) tem menor influência na condução do padrão de acumulação brasileiro.

Nenhuma fração, no entanto, conseguiu ainda se consolidar como hegemônica no bloco de poder, pois a trajetória futura do padrão de crescimento brasileiro não está clara. Assim, o Estado consegue aumentar sua autonomia relativa diante dos diversos interesses do bloco no poder, configurando oportunidade única para direcionar novos rumos.

Parece claro que, desde 2006, a economia brasileira entrou em um novo regime de crescimento, puxado pela demanda, no qual as políticas de distribuição de renda e o crescimento do mercado interno, com a incorporação de ampla parcela da população antes excluída do consumo de massas, tiveram papel fundamental. Especialmente em 2010/2011, entretanto, os limites ao modelo de crescimento baseado no mercado interno e na redistribuição da renda, combinado com a manutenção de juros elevados e apreciação cambial, mostraram-se claros. Observase um tipo de crescimento com elevação do consumo das famílias, mas com baixo dinamismo industrial, caracterizado externamente por uma acoplagem passiva às cadeias produtivas asiáticas que puxa para a reprimarização da pauta exportadora e para a especialização regressiva da estrutura produtiva.

O consumo cresce sem expansão da produção industrial devido ao vazamento da renda para o exterior com o aumento das importações de manufaturas 
e desarticulação das cadeias produtivas domésticas (aumento do conteúdo importado). Consequentemente, reduz-se o poder multiplicador das políticas sociais de transferência de renda e aumento do salário mínimo.

O setor privado, em particular a indústria de transformação, segue apresentando resultados decepcionantes em produção física e crescimento do PIB, suscitando debates sobre a desindustrialização. A capacidade ociosa desse setor em níveis elevados tem conduzido à retração dos investimentos privados a partir de 2011 que vinham sendo fonte importante do crescimento.

A manutenção da formação bruta de capital fixo tem dependido cada vez mais dos investimentos públicos (PAC e empresas estatais) que, por sua vez, são limitados pela manutenção da meta de superávit primário.

A atual fissura da hegemonia da fração bancário-financeiro no bloco no poder, que tem dado uma maior autonomia ao Estado, é o momento oportuno para se retomar o debate a respeito de um projeto de desenvolvimento e da recuperação dos instrumentos de planejamento e fomento ao desenvolvimento por parte do Estado. Nesse sentido, é preciso que o governo amplie sua capacidade de investir (sobretudo em infraestrutura) por meio da flexibilização da meta de superávit primário e de uma descentralização da gestão pública cada vez mais concentrada na presidenta Dilma, o que reduz em muito a velocidade de operacionalização dos processos e procedimentos governamentais.

Em contrapartida, permanece forte e em ascensão a fração dos segmentos industriais produtores de commodities e do agronegócio. Dado o fortalecimento de tais segmentos, vai ficando cada vez mais difícil para o Estado brasileiro deslocar parte do excedente gerado pelo setor para outros segmentos produtivos intensivos em tecnologia e produtores de bens salários. De qualquer forma, o futuro desse segmento dependerá fortemente da demanda chinesa e da capacidade daquele país em manter taxas elevadas de crescimento em um contexto de piora da crise na Europa e crescimento lento dos EUA.

\section{Considerações finais}

Este trabalho buscou mostrar que, no governo Lula, apesar da importância das políticas de redistribuição de renda e inclusão social, a manutenção das linhas gerais do regime de política econômica (com exceção da maior flexibilidade da política fiscal a partir de 2005) foi reflexo da manutenção do bloco no poder do período FHC. Em particular, reflexo da hegemonia do setor bancário-financeiro em um contexto de dependência financeira externa e dominância financeira da valorização que foram a verdadeira "herança maldita" do governo anterior. 
Assim, suscitou-se um debate a respeito do caráter do governo Lula, ou seja, em que medida se diria que era um governo voltado aos trabalhadores e aos mais pobres ou apenas uma continuidade com relação às políticas neoliberais do governo anterior. A dubiedade do governo Lula foi bem expressa no trabalho de Singer (2009), quando este autor coloca fatores determinantes para o realinhamento eleitoral em 2006 (a conquista do eleitorado de baixa renda por parte de Lula), como resultado da combinação das políticas distributivas e a expansão do consumo das massas com a manutenção da política econômica ortodoxa. Essa tensão refletiria o que o autor trata como sendo a existência de "duas almas" do partido dos trabalhadores (SINGER, 2010).

Argumenta-se que a análise de Singer é incompleta, na medida em que não trata da dinâmica dos extratos de cima, ou seja, das mudanças que se processaram no interior do bloco no poder. Na visão dos autores deste artigo, não foi o conservadorismo do subproletariado que o teria levado a votar em Lula, sendo suficientes, para tanto, as políticas sociais e de geração de renda e emprego. Ao contrário, a manutenção da política econômica jogou contra as conquistas sociais na medida em que limitou expansão ainda maior de tais conquistas, ainda incipientes para o tamanho do abismo social existente em nosso País. Por sua vez, a manutenção da política econômica ortodoxa é a chave para o entendimento de outro realinhamento, fundamental para compreender a sustentação do governo Lula, na medida em que se consolidou a hegemonia do setor bancário-financeiro mesmo durante o governo do partido dos trabalhadores, tradicionalmente crítico dessas políticas.

A análise anterior buscou mostrar que a combinação entre política social e conservadorismo da política econômica do governo Lula não foi, como sugerido por Singer, a fórmula que levou ao apoio do subproletariado com o governo, já que a política ortodoxa é oposta aos interesses dessa fração, porque restringe a capacidade financeira de o Estado manter e ampliar a agenda social. Dadas as diferenças expostas entre a fração reinante (a que teve sucesso eleitoral), a fração detentora (que detém os postos de comando dos centros de poder estatal) e a fração hegemônica (aquela que pode impor seu projeto ao restante da sociedade), ocorreu no governo Lula que as forças progressistas historicamente representadas pelo partido dos trabalhadores foram pouco a pouco atendidas com as políticas sociais, mas a vitória nas eleições não foi suficiente para questionar a hegemonia da fração bancário-financeira no bloco do poder - dada a permanência da situação de dependência financeira consolidada no governo FHC - que seguiu exercendo forte influência sobre a política econômica e sobre a nomeação para cargos dos principais centros de poder do Estado, em especial, o banco central.

A situação externa, entretanto, favorável no período de 2003 a 2007 e os desdobramentos da crise de 2008 criaram um cenário de redução da dependência 
financeira externa que, aos poucos, reduziu o poder de influência do setor bancáriofinanceiro. Este se valeu por anos daquilo que Paulani (2008) chamou apropriadamente de "estado de emergência econômico" que supostamente justificaria a adoção das políticas ortodoxas em virtude das frequentes e iminentes "ameaças à segurança nacional", decorrentes da possibilidade de fugas de capital, crises cambiais e da volta da inflação.

A redução da influência da fração bancário-financeira, em um momento em que ainda não se configura uma nova hegemonia, concedeu ao Estado uma rara autonomia diante das frações de classe. A presidenta Dilma deparou-se, então, com uma situação política bastante diferente daquela com a qual se deparou o presidente Lula em 2003.

Em contrapartida, a existência das empresas estatais e dos bancos públicos (Caixa Federal, Banco do Brasil e BNDES) foi fundamental no contexto de crise para a manutenção dos investimentos e do crédito. Eles se mostraram importantes centros de poder da ação do Estado não dominados pela influência da fração hegemônica.

É verdade que, até o presente momento, as iniciativas de política do governo, visando a estimular o crescimento, têm sido fragmentadas, sem organicidade, em parte pelo desmantelamento da capacidade de planejamento e atuação do Estado promovido pelas políticas neoliberais nos anos 1990. No pós-crise, contudo, cresce a influência, tanto no meio acadêmico como no governo, de que o Estado deva ter um papel fundamental na retomada do desenvolvimento.

A conjuntura econômica após a crise também mostrou os limites do modelo de crescimento que associa redistribuição de renda e consumo de massas com ortodoxia da política econômica, a qual perdurou no governo Lula. O resultado dessa combinação foi a expansão do consumo, mas com forte vazamento da demanda para o exterior, com claros limites quanto à sua sustentabilidade ou, ao menos, quanto às taxas de crescimento que dele se pode usufruir, seja pela especialização regressiva das exportações, seja pela desagregação das cadeias produtivas domésticas e a consequente redução dos efeitos multiplicadores das políticas redistributivas que expandem a demanda. Com o aumento da concorrência oferecida pela China, ávida por novos mercados em que possa desovar seus produtos manufaturados diante da crise nos EUA e Europa, está claro que, além de políticas de demanda, será necessário também ter políticas para ampliar os investimentos aumentar a competitividade e inovar o setor produtivo brasileiro.

Reorganizar o país para um novo ciclo de desenvolvimento, com inclusão social e autonomia, não será tarefa fácil diante da conjuntura internacional desfavorável e a ameaça real de uma acoplagem passiva à Ásia, já em curso. Dada, contudo, a redução de influência da fração bancário-financeira sobre as decisões da 
política econômica, essa é a oportunidade de o País romper definitivamente com a dominância financeira, com o padrão rentista de acumulação e a inserção externa subordinada, herdados do período FHC que, há quase duas décadas, tem impedido o crescimento sustentado.

\section{Referências bibliográficas}

ARESTIS, P.; SAWYER, M. Inflation targeting: a critical appraisal. The Levy Economics Institute of Bord Colleg, Sept. 2003. (Working Paper).

BARBOSA, N.; SOUZA, J. A. P. A inflexão do governo Lula: política econômica, crescimento e distribuição. In: SADER, A.; GARCIA, M. Brasil, entre passado e o futuro. São Paulo: Fundação Perseu Abramo/Boitempo, 2010.

BARBOSA, N. Oportunidades e desafios criados pelo desenvolvimento chinês ao Brasil. In: BRASIL e China no reordenamento das relações internacionais. Brasília: Fundação Alexandre de Gusmão, 2011.

BARRO, R.; GORDON, D. Rules, discretion and reputation in a model of monetary policy. NBER, Feb. 1983. (Working Paper Series, n. 1079).

BRUNO, M.; DIAWARA, H; ARAÚJO, E.; REIS, A. C.; RUBENS, M. Finance-led growth no Brasil: estatuto teórico, evidências empíricas e consequencias macroeconômicas. Revista de Economia Política, v. 31, n. 5, p. 730-750, edição especial, 2011.

BUSATO, M.; MOREIRA, R.; CAVALCANTI, A. A dinâmica inflacionária no new consensus: uma análise crítica. Análise Econômica (UFRGS), v. 27, 2009.

CARDOSO, F. H. As ideias e seu lugar: ensaios sobre as teorias do desenvolvimento. São Paulo: Vozes, 1980.

. Reforma e imaginação. Folha de São Paulo: Caderno Mais!, 10 jul. 1994.

. Desenvolvimento: o mais político dos temas econômicos. Folha de São Paulo: Caderno Mais! 28 maio 1995.

; FALETTO, E. Dependência e desenvolvimento na América Latina: ensaio de interpretação sociológica. Rio de Janeiro: Zahar, 1975.

CHESNAIS, F. O capital portador de juros: acumulação, internacionalização, efeitos econômicos e políticos. In: (Org.). A finança mundializada. São Paulo: Xamã, 2005.

CINTRA, M.; ACIOLY, L. O financiamento das contas externas brasileiras: 2003-2010. In: MONTEIRO, A. et al. Brasil em desenvolvimento 2011. Brasília: Ipea, 2012.

CODATO, A. N.; PERISSINOTTO, R. M. O estado como instituição. Uma leitura das “obras históricas" de Marx. Crítica Marxista, Editora Revan, n. 13, 2001.

. Sistema Estatal e Política Econômica no Brasil pós-64. São Paulo: Hucitec, 1997. 
FILGUEIRAS, L.; GONÇALVES, R. A economia política do Governo Lula. Rio de Janeiro: Contraponto, 2007.

FIORI, J. L. Os moedeiros falsos. Folha de São Paulo: Caderno Mais!, 3 jul. 1994.

GONÇALVES, R. Economia política internacional: fundamentos teóricos e as relações internacionais do Brasil. Rio de Janeiro: Elsevier, 2005.

GRAMSCI, A. Maquiavel, a política e o Estado moderno. Rio de Janeiro: Civilização Brasileira, 1978.

LOPREATO, F. O papel da política fiscal: um exame da visão convencional. Campinas: Unicamp. IE, fev. 2006. (Texto para Discussão, n. 119).

LOWY, M. As aventuras de Karl Marx contra o Barão de Munchhausen. São Paulo: Cortez, 1989.

MACEDO, A.; SANTOS, C. Além do curto prazo? Explorando os nexos entre a teoria pós keynesiana e a macrodinâmica de fluxos e estoques. Campinas: Unicamp. IE, 2008. (Texto para Discussão, n. 141).

MARQUES-PEREIRA, J.; BRUNO, M. Institucionalidade e política econômica no Brasil: uma análise das contradições do atual regime de crescimento pós-liberalização. In: VIANNA, S.; BRUNO, M.; MODENESE, A. (Org.). Macro para o desenvolvimento. Brasília: Ipea, 2010 .

MARX, K. O 18 Brumário e Cartas a Kugelmann. Rio de Janeiro: Paz e Terra, 2002.

OLIVEIRA, F. Crítica à razão dualista / O ornitorrinco. São Paulo: Boitempo, 2003.

Hegemonia às avessas. In: OLIVEIRA, F.; BRAGA, R.; RIZEK, C. (Org.).

Hegemonia às avessas: economia, política e cultura na era da servidão financeira. São Paulo: Boitempo, 2010.

OLIVEIRA, N. Neocorporativismo e políticas públicas. São Paulo: Edições Loyola/CEAS, 2004.

MARX, Karl. As lutas de classes na França (1848-1850). São Paulo: Global, 1986.

PAULANI, L. M. A crise do regime de acumulação com dominância da valorização financeira e a situação do Brasil. Estudos Avançados, São Paulo, USP, v. 23, p. 25-39, 2009.

Brasil Delivery: Servidão financeira e estado de emergência econômico. São Paulo: Boitempo Editorial, 2008

O Projeto neoliberal para a sociedade brasileira: sua dinâmica e seus impasses.

In: LIMA, J. C. F.; NEVES, L. M. W. (Org.). Fundamentos da Educação Escolar do Brasil Contemporâneo. Editora da Fiocruz, 2006.

; PATO, C. G. G. Investimentos e servidão financeira: o Brasil no último quarto de século. In: PAULA, J. A. (Org). Adeus ao desenvolvimento: a opção do governo Lula. São Paulo: Autêntica Editora, 2005. 
PINTO, E. Bloco no poder e governo Lula. 2010. Tese (Doutorado)-Instituto de Economia, Universidade Federal do Rio de Janeiro, 2010.

POULANTZAS, N. O Estado, o poder, o socialismo. Rio de Janeiro/RJ: Graal, 1985. . Poder político e classes sociais. São Paulo: Ed. Martins Fontes, 1977.

PRZEWORSKI, A. Marxismo e escolha racional. Revista Brasileira de Ciências Sociais, v. 3, fev. 1988.

SANTOS, T. A teoria da dependência: balanço e perspectivas. Rio de Janeiro: Civilização Brasileira, 2000.

SERRANO, F. Política macroeconômica e estratégia de desenvolvimento. In: SICSÚ, J.; CASTELAR, A. Sociedade e economia: estratégias de crescimento e desenvolvimento. Brasília: Ipea, 2009.

SETTERFIELD, M. Is inflation targeting inimical to employment? In: THE MEETINGS of the Eastern Economic Association. New York, Feb., 2007.

SINGER, A. Raízes sociais e ideológicas do lulismo. Novos Estudos Cebrap, n. 85, nov. 2009. nov. 2010.

A segunda alma do Partido dos Trabalhadores. Novos Estudos Cebrap, n. 88,

TAYLOR, J. B. Teaching modern macroeconomics at the principles level. The American Economic Review, v. 90, n. 2, p. 90-94, May 2000.

TEIXEIRA, R. A. Desenvolvimento, dependência e dominância financeira: a economia brasileira e o capitalismo mundial. Tese (Doutorado)-Instituto de Pesquisas Econômicas, Universidade de São Paulo, 2007.

. Positivismo, historicismo e dialética na metodologia da economia. 2003.

Dissertação (Mestrado)- IPE/USP, São Paulo, 2003. 